総

説

\title{
樹状細胞と肝疾患の免疫病態および治療
}

恩地森一

\section{Role of dendritic cells in the immunopathogenesis and therapy of liver diseases}

\author{
Morikazu ONJI \\ The Third Department School of medicine, Ehime University School of medicine
}

(Received January 9, 2004)

Key words_— Dendritic cells; antigen presentation; liver diseases; therapy; hepatitis virus

\section{I. はじめに}

長らく肝臓は免疫学からは免疫応答に鈍い臟器で あるとの認識であった。しかし，現在，肝は‘lymphoid liver’ と称されるほど免疫応答に重要な役割 を果たす臟器として認知されつつある. リンパ球幼 若化現象が発見されるまでリンパ球が静止状態にあ る無反応の細胞されていたことと似ている．自己免 疫性肝疾患やウイルス肝炎の発症, 進展にも肝免疫 は，免疫応答と寛容において大きな役割を果たして いる. 抗原提示樹状細胞は免疫応答の開始点にあっ て, 肝免疫においてもキーパーソン的な存在であ る. 肝の樹状細胞は定常状態を維持するために，全 身と肝局所の免疫寛容になくてはならない存在とな つている. さらに，この樹状細胞を用いて治療法の 開発が進み, 一部では臨床応用が試みられている. 筆者らの研究成果も含めて, 樹状細胞と肝疾患の免 疫病態, 治療法の開発について概説する.

\section{II. 樹状細胞の概要}

樹状細胞（Dendritic cells, DC）は最も抗原提示 作用が強く, 未感作 $\mathrm{T}$ 細胞を特異的に活性化でき る唯一の細胞である. その特徵を表 1 に示した ${ }^{1 \sim 3)}$. DC は骨髄幹細胞に由来し, 免疫監視細胞として全 身に分布する．種類と成熟段階により性状，機能， 分布が異なる。未感作 $\mathrm{T}$ 細胞, メモリー $\mathrm{T}, \mathrm{B}$ 細 胞, NK 細胞, NKT 細胞を活性する。未熟な DC は抗原を捕捉し, 取り込み, 消化, 分解し, MHC

愛媛大学内科学第三講座（消化器, 内分泌 - 代謝, 糖 尿病内科）
分子に結合して提示する。 その過程で末梢組織から 所属リンパ系器官に移動し成熟する. 中枢性および 末梢性免疫寛容を誘導する. さらに一部の DC 前駆 細胞は 1 型インターフェロンを産生して, 自然免疫 に関与している。 マクロファージ遊走阻止因子, TNF- $\alpha$ なども産生して炎症に関与している.

DC には多くの種類があるが，その分類は混沌と している. 現時点で概括すると, myeloid DC と plasmacytoid DCの分けられる。 myeloid DC は IL-12 などの Th1 系サイトカインを産生し, Th1 系の免疫応答を誘導する. 定常状態では主に免疫寛 容に働いている。一方, plasmacytoid DC は Th2 系の免疫応答を誘導する。 ウイルス感染では Th1 系の免疫応答を誘導することもある. しかし, 通常 は免疫寛容に作動していることが多いとされている. 1 型インターフェロンと IL-6 を産生し， B 細胞の 形質細胞への誘導に必須の DC である ${ }^{4)}$. その概要

\section{表 1 樹状細胞の特徵}

1）免疫監視機構

分布臟器 ; 全身, 抗原捕捉の後所属リンパ器官に移動

2) 抗原提示能

抗原の捕捉, 処理, 提示を行う

低レベルの抗原でも強い免疫応答を誘導する

3）形態; 成熟ないしは活性化すると多数の樹枝状突起を持つ

4) 多型性 : 種類, 成熟過程, 分布臓器により性状が異なる

5）免疫応答の開始点で作用

未感作 $\mathrm{T}$, メモリー T, B, NK, NKT 細胞を刺激

6）免疫寛容を誘導

中枢性，末梢性免疫寛容を誘導

7）活性化された NK 細胞により未熟な樹状細胞は除去される

8) 自然免疫に関与

1 型インターフェロン産生樹状細胞の存在 


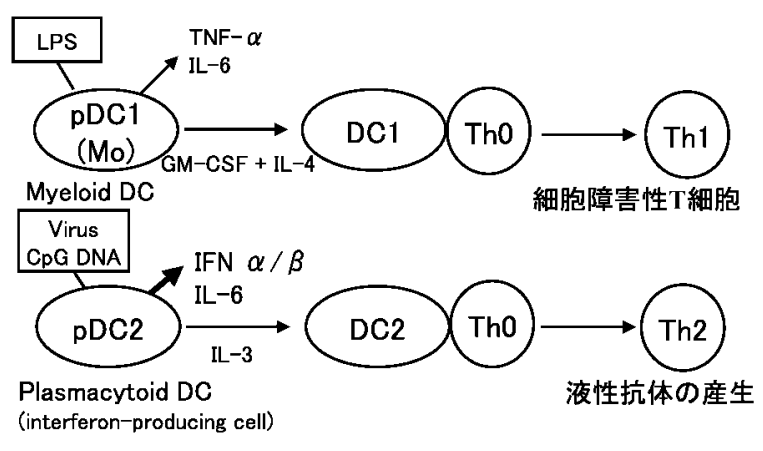

図 1 樹状細胞の種類と免疫応答誘導

を図 1 に示した，DC は IL-6 を介して制御性 T 細 胞（Tr）を制御するとともに， DC が未感作 $\mathrm{T}$ 細胞 に作用するところを $\operatorname{Tr}$ が抑制している． DC と Tr の関係は解明が進んでいる.

\section{III. 肝免疫の特性}

肝は全身の生体防御機構, 特に免疫機構において 重要であることが, 再認識されてきている. 肝免疫 の特性を表 2 に示した ${ }^{5)}$. 場としての特性には，胎 生期に造血器であったこと, 消化管や脾からの門脈 血を受け入れていること, 代謝産物の排出路として 粘膜免疫を形成している胆管・胆道系が存在するこ となどがある。また，免疫学的には未熟な DC, $\mathrm{NK}, \mathrm{NKT}, \gamma \delta \mathrm{T}$ 細胞, $\mathrm{CD} 8$ 陽性 $\mathrm{T}$ 細胞が多いこ と，HLA 不適合でも移植が可能なことなどがあ る．肝は免疫担当細胞が豊富で，機能も旺盛である ことから “lymphoid liver”とも言える.また，T 細胞や DC を大量に処理する場ともなっている。こ れらの特性は肝疾患での免疫異常のみならず，全身 の免疫と生体防御を知る上で重要である.

\section{1. 肝亡自然免疫, 獲得免疫}

免疫系は自然免疫と獲得免疫に大別される. 自然 免疫の細胞成分として食食細胞, NK 細胞, NKT 細胞， $\gamma \delta \mathrm{T}$ 細胞などがある。そのレセプターは CD14, Toll-like receptor (TLR), マンノースレセプ ターなどが知られている。形質細胞様樹状細胞 (plasmacytoid DC (PDC)) はサイトカインである 1 型インターフェロンを産生して自然免疫として働 く. 自然免疫を構成する細胞は肝に多く存在して, 門脈と動脈の血液が流入する類洞を形成している. また, 自然免疫に関与する蛋白成分の多くは肝で産 生されている. 外界異物（病原体）を認識するレセ プターとして Toll-like receptor（TLR）があるが,
表 2 肝免疫の特性

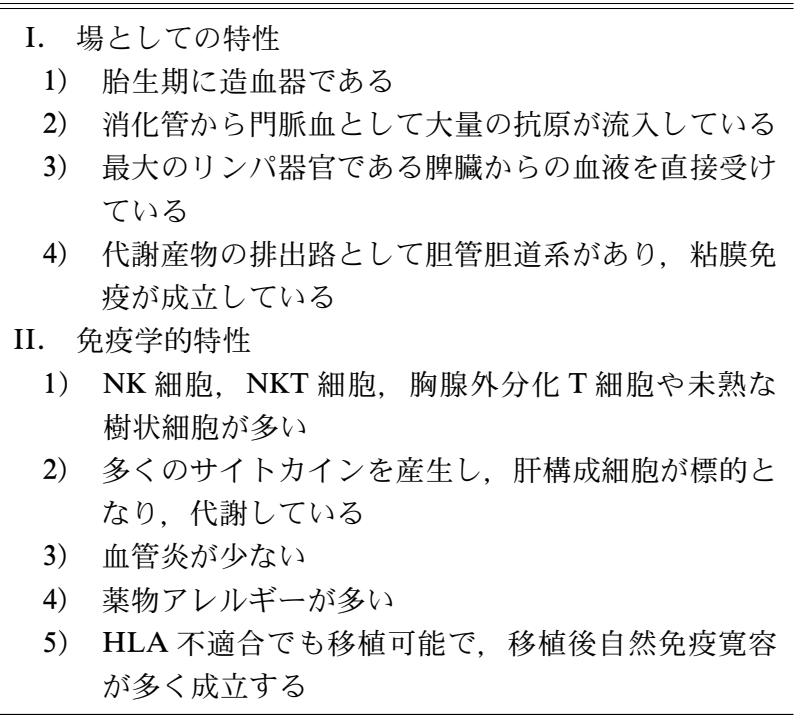

肝には TLR を発現する免疫担当細胞が多数存在し ており，自然免疫が肝で作用していることを示して いる. 感染症の成立や腫瘍発生の阻止に自然免疫は 大きな役割を果たしている.

一方, 獲得免疫は抗原に対して, 応答の速さと強 さが記憶 $\mathrm{B}, \mathrm{T}$ 細胞の成立により獲得された。獲得 免疫は肝の生体防御や疾患の成立に大きな役割を果 たしている. ウイルス肝炎や自己免疫性肝疾患で細 胞障害性 $\mathrm{T}$ 細胞（CTL）が大きな役割を果たして いることは確実である. 肝疾患の成立には獲得免疫 がより大きな役割を果たしている.

\section{2. 肝の構成細胞と免疫}

肝の上皮細胞には 2 種あり, 胆管細胞は肝のすべ ての細胞の 3〜5\%を，肝細胞は肝臓全体では 2500 億万個存在する. 肝非実質細胞としては類洞壁細胞 と肝リンパ球系細胞がある. 類洞壁細胞としてクッ パー細胞, 類洞内皮細胞, 星細胞と Pit 細胞が, 肝 リンパ球系細胞として NKT 細胞, $\mathrm{NK}$ 細胞, $\mathrm{T}$ 細 胞， $\gamma \delta \mathrm{T}$ 細胞，DC などが存在する (図 2)。Pit 細 胞は NK 活性があり, NK 細胞と同一とされてい る $^{6 \sim 8)}$. 肝には流血中の $\mathrm{T}$ 細胞や DC が大量に入る が, 抗原非特異的な方法でアポトーシスに陥り処理 され，免疫応答を起こさないようになっている．あ る意味で, $\mathrm{T}$ 細胞と $\mathrm{DC}$ にとって肝は墓場である.

一方, 免疫記憶 $\mathrm{T}$ 細胞は肝のアポトーシスを誘導 しようとする作用に抵抗性である. 肝は免疫担当細 胞を処理するとともに保護的に作用する臓器とも言 える。 


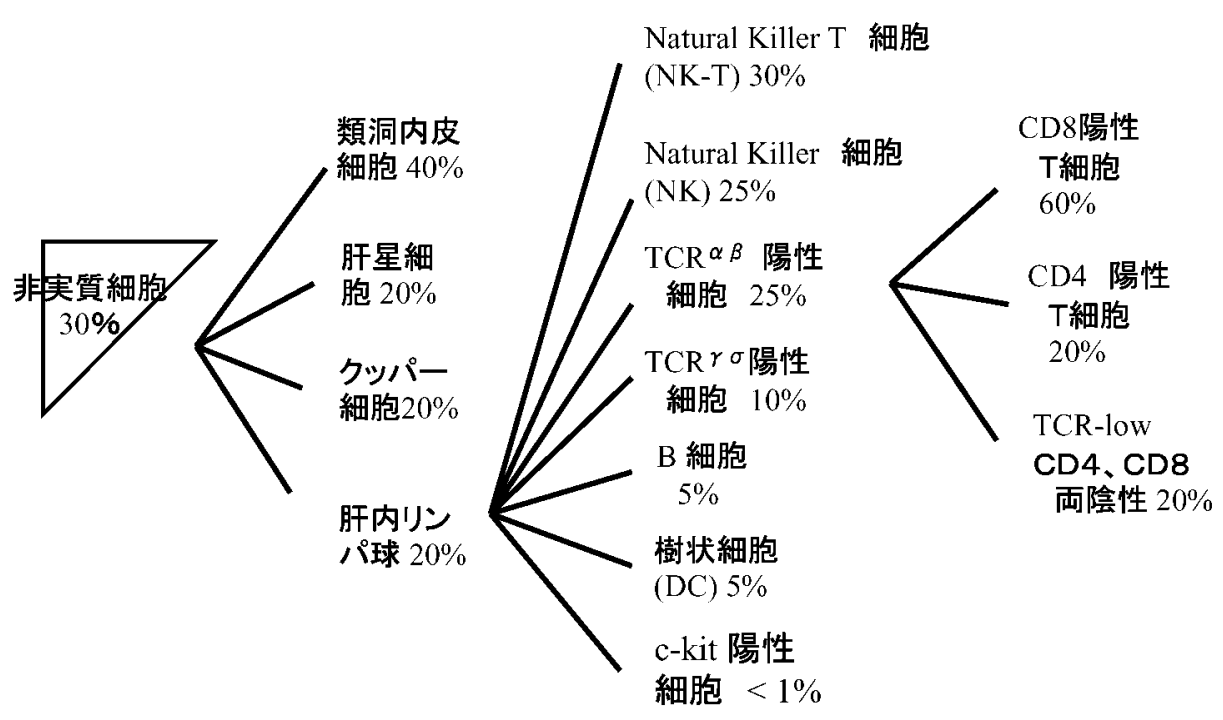

( Mehal W. Z, et al. Gastroenterology, 2001; 120: 250-260)

図 2 ヒト及びマウスの肝に抢ける非実質細胞の構成

\section{1）クッパー細胞}

類洞壁細胞の 1 つである. 多くのサイトカインを 産生して, 免疫応答や炎症の成立に大きな役目を果 たしている. クッパー細胞には貧食能や抗原提示能 があり，組織中にあるマクロファージの $80 \%$ を占 めている. クッパー細胞は単球と異なり貧食能が強 く，流入する異物を貪食して，生体防御の役割を果 たしている. クッパー細胞は細菌およびその成分を 貪食する。エンドトキシンはクッパー細胞に貧食さ れ，生理的条件では大循環に流出しないが，門脈/ 静脈でのシャントが形成されると, 全身への影響が 出やすくなる，アポトーシスに陥つた細胞を食食し 免疫寛容を維持している. TNF- $\alpha$ などのサイトカ インを産生して，炎症にも関与している． In vitro の実験ではあるが，クッパー細胞によって産生され た一酸化窒素は $\mathrm{T}$ 細胞の活性化を抑制する。アル コール性肝障害などでクッパー細胞機能が障害され るとエンドトキシンなどの有害物質が類洞を越え肝 内に流入するとともに，大循環にも流出する．エン ドトキシンにより多種のサイトカインやケモカイン がクッパー細胞から産生されると, 肝障害はさらに 進展する，障害肝では末梢血単球に由来するマクロ ファージも浸潤し，常在するクッパー細胞とともに 活性化することで，壊死，線維化，再生など肝病態 の成立に関与している. 特に劇症肝炎の成立と進展 にクッパー細胞とマクロファージが重要である。そ の過程では多彩なサイトカイン, ケモカインが作動 している.

\section{2）肝星細胞（伊東細胞）}

肝星細胞はビタミン $\mathrm{A}$ を含む脂肪貯蔵細胞であ る. 肝星細胞の近くには膠原線維が多く見られ, 多 くのサイトカインに刺激され膠原線維や細胞外基質 の構成成分を産生する。 すなわち, 線維化に直接関 与している. TGF- $\beta$ や血小板増殖因子などで活性 化する，活性化された星細胞はレプチンを産生す る.レプチンは星細胞を刺激して肝線維化を促進す る.一方，アデイポネクチンは線維化を抑制する. 星細胞は免疫応答には直接関与することは少与い.

\section{3）類洞内皮細胞}

類洞内皮細胞は肝の類洞壁を形成する主要な細胞 である。一酸化窒素などを産生して類洞の血流調節 にも関与している. クッパー細胞機能が低下したと きには流血中の異物を取り込み処理する. CD4 陽 性である. MHC classII を表出し抗原提示作用もあ る. スカベンジャーレセプターをはじめとしてさま ざまなレセプターがある，少量ではあるが，プロス タグランジン, $\mathrm{IL}-1, \mathrm{TGF}-\beta$ などを産生する.

IFN-inducible protein 10b (IP-10) や monokine-induced by IFN- $\gamma$ (MIG) が類洞内皮細胞に発現して おり, CXCR3 陽性リンパ球を肝実質内へと遊走さ せる年.

\section{4）肝 NK 細胞（Pit 細胞）}

Pit 細胞は肝に常在する NK 細胞である. NK 細 胞 $(\mathrm{CD} 3-\mathrm{CD} 56+)$ は, 抗原の感作なくても自然 に細胞障害機能を持つ。特に MHC class I を発現 していない細胞を強く障害する．肝に流入する未熟 
な樹状細胞を処理する。生体の NK 活性は肝が最大 である．肝内では Pit 細胞として多くの NK 細胞が あり, 腫瘍やウイルス感染の成立と進展阻止に重要 な役割を果たしている，サイトメガロウイルス感染 マウスでは 1 型インターフェロンによってケモカイ ン CCL3 $($ MIP1 $\alpha)$ が合成され NK 細胞の集積を促 進する. CCL3 が不足すると NK 細胞の集積と防御 免疫が低下する. $\mathrm{NK}$ 細胞はインターフェロン $\gamma$ を 産生し, 肝細胞や類洞内皮細胞によるケモカイン CXCL9（MIG）の分泌を促進する．肝 NK 細胞は $\mathrm{T}$ 細胞を肝に呼び込むことにより, $\mathrm{T}$ 細胞の免疫応 答に関与していると考えられる。

\section{5）リンパ球}

肝臓のリンパ球は, 肝組織 100 グラムあたり $10^{6}$ 細胞程度で，成人でほぼ $10^{9}$ から $10^{10}$ 存在し，全身 の約 $10 \%$ 程度を占めている7)。

末梢血リンパ球と肝臓内のリンパ球とは構成比率 に違いがある．肝には CD8+ T 細胞比率が多い. 末梢血では $\alpha \beta \mathrm{T}$ 細胞が 7 割近くを占めているのに 対して, 肝内では 3 割程度にとどまる.すなわち, 肝では胸腺外分化 $(\gamma \delta) \mathrm{T}$ 細胞が多い。一方, 肝内 には NK 細胞，NKT 細胞が末梢血よりも高い割合 である。特に全身ではわずか $2 \%$ 程度しかない NKT 細胞が，肝では $18 \%$ を占めている7)。CC ケ モカインの 1 つである CCl17/TARC は門脈や肝静 脈内皮細胞に発現し, リンパ球や DCに作用する.

Stromal cell derived factor-1 (SDF-1) は胆管細胞に 発現して, CXCR4 陽性の単球や $\mathrm{T}$ 細胞を遊走させ る. Secondary lymphoid tissue chemokine (SLC) は 二次リンパ濾胞の高内皮細静脈 (HEV) や $\mathrm{T}$ 細胞 領域に発現しており，そのレセプターである CCR7 を介してリンパ球の血管外遊走や $\mathrm{T}$ 細胞領域への 誘導に関わっている. 原発性硬化性胆管炎 (PSC) の門脈域血管内皮にSLC が異所性に発現し, CCR7 陽性リンパ球の遊走に関係している。 また, 肝障害マウスモデルでは, SLC は門脈域の輸入リ ンパ管内皮細胞に発現し, 抗 SLC 抗体は樹状細胞 の portal-associated lymphoid tissue (PALT) への 集積を阻止した。このことから，SLC はPALT 形 成に関与しているとされている10).

肝疾患患者の末梢血では, $\mathrm{T}$ 細胞と CD8 陽性 T 細胞数が減少することが多い。一方, 肝組織内に CD8 陽性 $\mathrm{T}$ 細胞が集簇して，末梢血と肝組織内で は鏡像関係となっている. 肝炎の増悪時にそれが顕 著となる，なお，マウスの灌流実験で活性化された
CD8 陽性 $\mathrm{T}$ 細胞は優先的に肝に取り込まれる。末 梢血の $\mathrm{T}$ 細胞は, 非特異的抗原に対して免疫応答 は低下し, 一方, 特異抗原には高い免度応答を示 す. ウイルス感染, 腫瘍, 自己免疫性肝疾患におけ る $\mathrm{T}$ 細胞の抗原特異性を明らかにすることは重要 である. B 型, C 型急性肝炎, 慢性肝炎において $\mathrm{HBV}$ および $\mathrm{HCV}$ 特異的 CD4 および CD8 陽性 $\mathrm{T}$ 細胞が誘導され解析されている. 肝細胞癌患者の末 梢血から $\alpha$ fetoprotein を特異的に認識する $\mathrm{T}$ 細胞 が誘導された。原発性胆汁性肝硬変 (PBC) では 抗ミトコンドリア抗体の対応抗原に特異的な CD8 陽性細胞障害性 $\mathrm{T}$ 細胞が末梢血および肝組織由来 リンパ球から誘導されている。これらの細胞障害性 $\mathrm{T}$ 細胞が認識する特異的な抗原が確実に同定できれ ば，抗原特異的な免疫療法の道が開ける。

一方，制御性 $\mathrm{T}$ 細胞（Tr）は CD4 陽性細胞の 5 〜 10\%を占め, $\mathrm{CD} 4$ 陽性, $\mathrm{CD} 25$ 陰性 $\mathrm{T}$ 細胞の増 殖を抑制して効果（effector） $\mathrm{T}$ 細胞を抑制する. 自己免疫性肝炎, 肝細胞癌や C 型慢性肝炎で低下 している.

$\mathrm{NKT}$ 細胞 $(\mathrm{CD} 3+\mathrm{CD} 56+)$ は $\mathrm{NK}$ 細胞と $\mathrm{T}$ 細 胞レセプターをともに持つ. 肝や骨髄などの胸腺外 の組織に多く分布している. 肝内リンパ球の 2 割近 くを占めている。肝の NKT 細胞のほとんどが $\mathrm{CD} 4+$ か CD4-CD8-であり, Vo14+である.

肝細胞には, NKT 細胞の分化と活性を促す CD1d 分子が多く発現して全身の NKT 細胞に影響を及ぼ している11)。マウスでは肝再生時に NKT 細胞が増 加する. 肝内の CD8+ NKT 細胞が新生時のトレラ ンスに関与しているとの報告がある. NKT 細胞は 転移性肝癌モデル動物で, 肝転移を阻止することが 証明された。マウスに NKT 細胞を誘導する $\alpha^{-}$ galactosylceramide を投与すると, 肝 NKT 細胞が 活性化を受け，Fas-Fasリガンド系を介して肝障害 が惹起される。抗腫瘍傷害活性以外に ConA を用 いたマウス急性肝炎モデルで肝障害の発生と進展 し，さらに，門脈虚血再灌流肝障害に関与していた。 $\alpha$-galactosylceramide を投与したマウスではマラ リア感染の肝病期の免疫応答を誘導する. HBV 卜 ランスジェニックマウスに $\alpha$-galactosylceramide を 投与すると NKT 細胞の作用により HBV の増殖は 抑制される. C 型慢性肝炎では肝内の炎症や線維化 の程度に応じて CD56+ T 細胞の比率が増加してお り， NKT 細胞が肝障害に関わっている.

通常, 自己免疫疾患では末梢血 NKT 細胞の割合 
が増加する．PBC 患者の肝内には健常者と比較し て, 約 3 倍のヒト CD1d- $\alpha$-galactosylceramide テト ラマー陽性細胞がみられ，これが PBC の病態に関 つていると考えられている，一方，CD56+ 細胞が 減ると肝細胞癌になりやすいといわれている.

ヒトやマウスでは $\gamma \delta \mathrm{T}$ 細胞は肝, 脾, 未梢血の リンパ球の $5 \%$ 程度を占めている. 微生物やストレ ス蛋白などと反応し，IFN- $\gamma$ などを産生して感染 防御に働く。一方で in vitro の実験では IL-10や $\mathrm{TGF}-\beta$ を産生して肝癌細胞株に対する細胞障害活 性を下げる. $\gamma \delta \mathrm{T}$ 細胞の活性と肝細胞癌発生との 関係が推測されている。 $\gamma \delta \mathrm{T}$ 細胞が $\mathrm{C}$ 型慢性肝炎 患者の肝組織内で増加し, それらが細胞障害活性を 持っている12).

肝内には progenitor, immature, mature な DC な どさまざまな DC がある。肝にある DC は未熟な状 態であるものが多い. 抗原を取り込むと所属リンパ 節に移動し, 成熟して, 未感作 $\mathrm{T}$ 細胞への抗原提 示を行う13,14). DC には主に Th1 系に作動する Myeloid DC と主に Th2 系に作動する PDC の 2 つ のサブセットがある. 肝内にもこの 2 つの DC が存 在する. 2 つの DC ともに, 腫瘍, 移植およびウイ ルス感染に大きな役割を果たしている.

\section{3. 肝免疫のホメオスターシス}

肝には，門脈血を介して，消化管から流入したエ ンドトキシンなどの抗原物質が大量に入ってくる.

しかし多くの物質には反応を起こさず，免疫寛容を 誘導して，全身への影響を抑えている．その免疫寛 容の状態を維持する機構に抗原提示細胞が関与して いる. 抗原提示細胞には DC, クッパー細胞と類洞 内皮細胞がある。マウスにおいて肝の DC は, 骨䯣 から得た DC と比較して, 免疫寛容に働くことが証 明されている. クッパー細胞と類洞内皮細胞は大量 に流入する抗原を処理して免疫寬容を誘導する15).

一方，DC は免疫応答も誘導する ${ }^{16)}$ 。また, 免疫寬 容性（tolerogenic） DC は T 細胞に免疫寛容を誘導 する.これらの抗原提示細胞により免疫応答と寛容 のバランスが維持されている. その関係を図 3 に示 した．肝障害により，そのバランスがくずれるとさ まざまな病態が生じる. 類洞壁細胞によって構成さ れている生物学的なフィルターが障害されエンドト キシンなどの有害物質が流入すると, 各種のサイト カインが産生されサイトカインネットワークが形成 され肝障害は進展する。 サイトカインの中で免疫抑

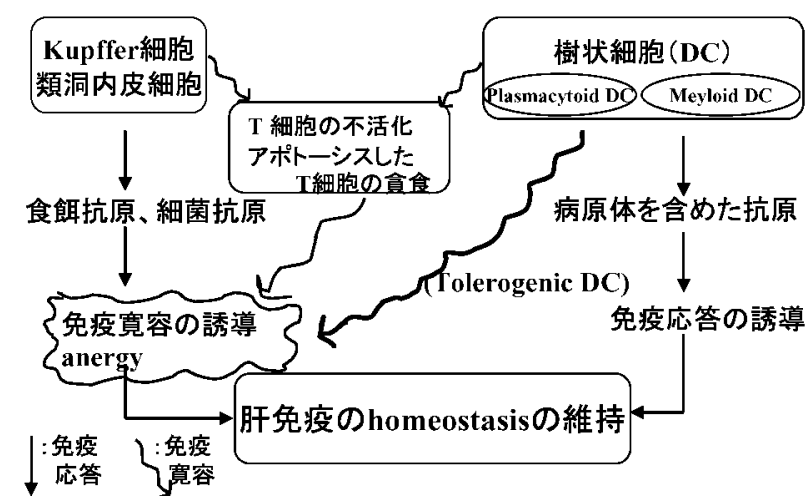

図 3 肝免疫のホメオスターシスと抗原提示細胞

制作用のある IL-10 は肝で産生されやすい傾向に ある．IL-10 は樹状細胞の成熟を抑制するが， 1 型 インターフェロンは促進する．免疫寛容が破綻する と自己免疫が生じる，また，免疫応答が抑制される と生体防御が障害され易感染性, 易腫瘍転移性状態 となる。

肝に大量にあるマクロファージ（クッパー細胞） や DC による肝局所の抗原提示を介して, $\mathrm{T}$ 細胞の 不活性化, 免疫寛容やアポトーシスが引き起こされ ていると考えられている ${ }^{17)}$. 肝 $\mathrm{T}$ 細胞の免疫寛容 は移植肝の良好な生存状態を誘導維持する。一方, 腫瘍の肝転移を容易にしている可能性も想定される.

\section{4. 臟器相関と肝免疫}

肝は，消化管からは入るさまざまな抗原やタンパ クを処理し, 全身の免疫応答を制御している. 消化 管リンパ装置から免疫担当細胞が肝に入っている.

また, 消化管で産生された TGF- $\beta$ などのサイトカ インが肝に流入して肝の機能に影響する. 免疫応答 および免疫寛容の両面から, 肝は消化管の影響を受 けている.

肝には脾から直接門脈血が流入している. 脾から 肝へ, サイトカインなどの免疫物質が流入する.ま た, 免疫担当細胞も流入していることが推定され る. ラットでは脾からの門脈血には CD8 陽性 $\mathrm{T}$ 細 胞が多い．脾を摘出したラットではアルコール性肝 障害が重篤にならない．本態性門脈圧六進症の原因 として脾臟の因子が想定されている.

\section{B 型肝炎と樹状細胞}

地球上には発展途上国を中心に, B 型肝炎ウイル ス (HBV) の持続感染者（キャリア）が 3 億 5 千 万人存在し, 年間 100 万人が死亡している. 日本で 
は約 150 万人の $\mathrm{HBV}$ キャリアがいて，年間 5 千人 が肝細胞癌で死亡している. また，母子感染阻止事 業は国の施策として定着しているが，最近では性的 感染により若者を中心に感染が広まり, 急性肝炎や 劇症肝炎が発生している.

HBV 感染が生下時から 3 歳未満で感染すると持 続感染が成立し HBV キャリアとなる. HBs 抗原が 消失することは例外的で, 強固な持続感染が成立す る. 日本の $\mathrm{HBV}$ キャリアの $90 \%$ 以上はゲノタイプ Cであり, 成人初感染では免疫不全状態などがない 限りキャリアになることは例外的である.ゲノタイ プ A や D では 10\%以下ではあるが成人初感染でも キャリアとなる，思春期頃まで，キャリアはウイル 又量が多く肝障害のない無症候性キャリアの時期を 経て, 慢性肝炎, 肝硬変と肝炎が進展する。この期 間にウイルス量は減少するとともに, 主としてウイ ルスのコアおよびプレコア領域の変異株が増加す る. 進行した慢性肝炎ないしは肝硬変の時期を迎え て HBe 抗原から抗体にセロコンバージョンが起こ り, 肝炎は終息し, ウイルス量は急激に減少する. HBV は宿主の遺伝子に組み込まれる. 肝細胞癌は 慢性肝炎から肝硬変患者に高頻度に併発する。

肝障害のない HBV キャリアが存在することか ら, 肝炎すなわちウイルスの排除は宿主の免疫学的 機構で行われている. 特に CD8 陽性の細胞障害性 $\mathrm{T}$ 細胞が関与していることが観察されている．CTL の標的抗原はコア蛋白や HBs 抗原とされている. 中和抗体は HBs 抗体である.

\section{HBV トランスジェニックマウスにおける基 礎的研究}

HBV は in vitro での感染実験は不可能であり, 免疫の実験系には大きな制約がある，筆者が DC の 実験を開始した 1988 年頃はマウスでしか DC を同 定するマーカーがなく, DC の単離もマウスのみで 可能であったので, HBV を産生するトランスジェ ニックマウス（HBVTM）を使用した。このマウス は胎生 16 日から HBs 抗原やウイルス粒子を産生し ているが肝炎は発症しない。 ヒトの無症候性キャリ アに近いモデルである， $\mathrm{T}$ 細胞依存性抗原である KLH に対する抗体産生も低下しており, 脾臓の DC 機能低下と関係していた ${ }^{18)}$. DC の機能低下は 外来性にインターフェロン（IFN） $\gamma$ を投与すると 回復した ${ }^{19)}$. 次に HBV の特異抗原でも同様の現象 を確認した。すなわち，HBs 抗原で感作した
HBVTM の T, B 細胞に正常マウスからの DC を加 えて培養すると HBs 抗体産生が観察された ${ }^{20)}$ 。こ のことから, 胎生 16 日から HBV を産生している HBVTM でも HBs 抗原に対して完全な免疫寛容状 態にはないことが明らかとなった。以上から， HBV 感染による免疫不全は抗原提示レベルにあっ てDC の機能障害が主因であり, 完全な免疫寬容状 態にはないと結論された.この成績は当時同じ時期 に発表された “危険” モデル説ともよく符号してい た。なお，それ以前に，筆者らはヒト B 型慢性肝 炎の肝内で形成されるリンパ濾胞中の滤胞性 DCに HBs 抗原が存在することを観察し, 未梢血中に HBs 抗体が観察されない時期からすでに HBs 抗体 が産生されている可能性を指摘していた ${ }^{21,22)}$. 以上 の実験結果から DC を特異抗原 (HBs 抗原) で刺 激し, DC 機能を回復すれば HBV の持続感染は終 息される可能性を考え, 後に述べる HBs 抗原によ るワクチン治療を開発することに着手した。 マウス 肝非実質細胞を GM-CSF 存在下で 1 週間培養して 得られた DC 前駆細胞は IL-10 産生が強く, 脾 DC よりも未熟で貪食能が強く, 同種混合培養試験での $\mathrm{T}$ 細胞幼若化補助能は弱かったが, HBs 抗原刺激 では Th1 関連サイトカイン誘導は可能であっ た ${ }^{23)}$. すなわち, 肝 DC 前駆細胞が免疫応答にも作 用していることを確認した。

\section{2. ヒト B 型慢性肝炎における DC 機能}

B 型慢性肝炎の肝組織内には CD83 陽性の成熟し た DC が浸潤していた ${ }^{24)}$ 。また患者末梢血から採取 した末梢血 $\mathrm{DC} の \mathrm{~T}$ 細胞幼若化補助機能は健常者 に比べて有意に低下していた ${ }^{25)}$. その原因の 1 つに は DC の IL-12 産生能の低下が関与していた。そ の成績を図 4 に示した. 同様の成績は他の研究者か らも報告されている26,27). 患者末梢血 DCに HBV が存在するか否かを HBVDNA の in situ hybridization 法により解析した. その結果, DC に HBVDNA が存在し, さらに, HBVRNA も存在すること が明らかとなった．したがって，HBV はDCに感 染し，その中で増殖している可能性が示された。 な お, 以前から患者末梢血リンパ球には HBV が存在 することは報告されてきた．図 5 に示したように, 抗ウイルス剤であるラミブジンを投与すると, DC 機能は回復した ${ }^{28)}$. さらに, 後に述べるワクチン療 法をラミブジン投与に併用すると, DC 機能はさら に改善した，以上，HBVTM およびヒト HBVキャ 


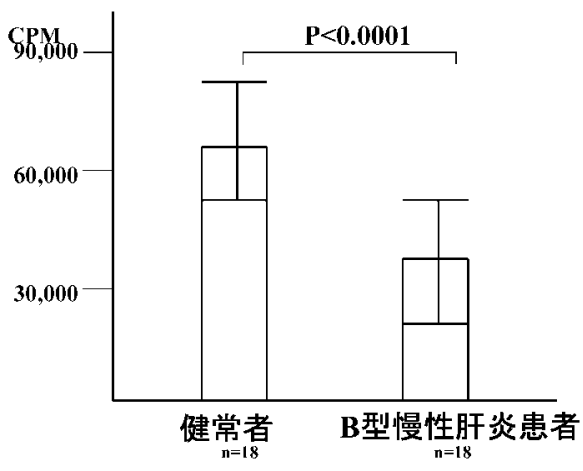

図 4 B 型慢性肝炎における末梢血樹状細胞による $\mathrm{T}$ 細胞幼 若化反応補助能（allogenic MLR）

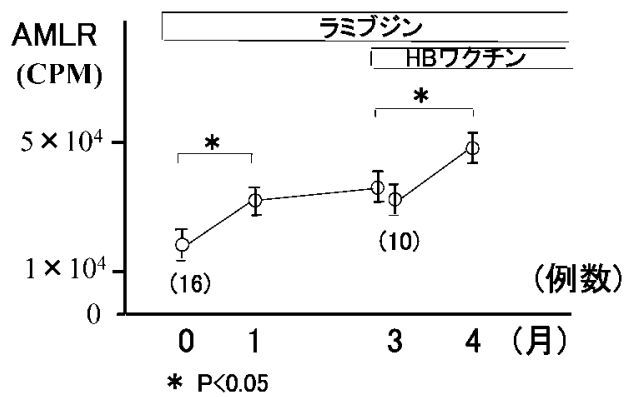

図 5 B 型慢性肝炎に対するラミブジン, HB ワクチン併用 療法時における樹状細胞の $\mathrm{T}$ 細胞幼若化補助能

リアの実験成績から，HBV キャリアでは DC 機能 は低下しているが，HBV 量を減じたり，特異的な 免疫療法を行うと回復することが明らかとなった ${ }^{29}$.

\section{HBV ワクチン療法の開発}

HBs 抗原投与により DC 機能が回復することか ら, HBs 抗原ワクチン療法の開発を開始した。 HBVTM に HBs ワクチン $10 \mu \mathrm{g}$ を腹腔内に 1 カ月 に 1 回の間隔で注射すると, 8 力月頃から血中 HBs 抗原の陰性化が始まった ${ }^{30)}$. 4 回の実験で, 総数 111 匹のマウスに投与したところ，74 匹，66\%で HBs 抗原が消失し，42 匹 $38 \%$ に HBs 抗体が出現 した。肝臟内の HBVDNA も減少した ${ }^{31 \sim 33)}$. HBV の DNA ワクチンを作成して筋注すると, 筋細胞中 に HBs 抗原が発現し，その周囲に DC が集積して きた。この HBVDNA ワクチンを HBVTM に, 1 回のみの投与で, 15 匹中 14 匹，93\%で HBs 抗原 が消失し，4匹 $27 \%$ で HBs 抗体が出現した ${ }^{33)}$.

次に, HBs 抗原をDC にパルスして HBVTMに 投与する DC-based vaccine therapy の開発を試み た ${ }^{34)}$. HBVTM の脾臟から DC を単離し, HBs 抗 原を DC にパルスした。その DC を HBVTM の腹 腔内に投与すると 2 回の投与で HBs 抗原は 13 匹中

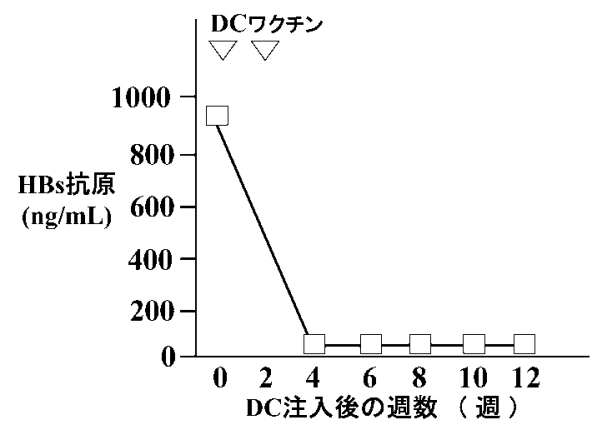

GPT，GOTの上昇なし、肝炎の組織所見なし

図 6 HBs 抗原をパルスした樹状細胞により治療した HBV transgenic mouse に打ける HBs 抗原の推移

13 匹，100\%消失した（図 6)，HBVDNA ワクチン に匹敵する効果であった。DNA ワクチンと異な り，ヒトへの応用も容易であり，現在，B 型慢性肝 炎患者への治験を開始している。 今後，B 型肝炎に 限らず，C 型肝炎， HIV 感染など持続感染するウ イルス感染症への応用も期待される.

\section{HBs 抗原樹状細胞ワクチンの応用}

HBs 抗原をパルスした DC ワクチンは HBV キャ リアへの治療ワクチンのみでなく, 予防ワクチンと しての可能性も期待される ${ }^{35)}$. その応用範囲として は，1）通常のワクチン接種のみでは抗体産生が生 じない，いわゆる非応答者，2）HIV 再感染で免疫 不全状態にある患者，3）移植後などで免疫抑制剂 投与により免疫不全にある患者などがその対象とな る. 特に, HBV による劇症肝炎, 肝硬変, 肝細胞 癌で肝移植を行った患者には, HBV 感染を予防す るために，長期にわたり抗ウイルス剂と高力価 HBs 免疫グロブリンの投与が必要である. 医療経 済上でもこの DC ワクチンが期待される。そこで, HBVTM を用いて免疫抑制剂投与中でもこのワク チンが有効か否かを検討した。FK506 投与で免疫 抑制状態にあっても，さらに HBV キャリア状態で さらに免疫抑制剂を投与されていても, HBs 抗体 が出現し，DCワクチンが有効であることを確認し た ${ }^{36)}$. 次に，ヒトへの応用に向けて，まず健常者に HBs 抗原 DC ワクチンを投与して，その安全性を 確認した. HBs 抗原 DC ワクチンを投与すると HBs 抗体の出現をみている ${ }^{37)}$. 副作用はなく, 自 己抗体も変動しなかった．ただし，抗原をパルスし た後，DCがどのように変化した時期に投与するか には技術的問題が残されている。いわる“コツ” が存在する. 


\section{C 型肝炎と樹状細胞}

C 型肝炎ウイルス（HCV）感染者はわが国では 180 万人存在して，そのほとんどが慢性肝疾患であ る。慢性肝炎, 肝硬変の $85 \%$ 以上, 肝細胞癌の 80 \%が HCV による. HCV は成人初感染でも持続感 染（キャリア化）が成立する. 1 型インターフェロ ン治療により約 50\%はウイルスを駆除でき，肝炎 は終息して, 肝細胞癌への進展を阻止できる，血液 を介して感染する. 若者の間では覚せい剂のまわし 打ちで感染している. ワクチンは実用化されていな い. HCV に感染した直後の急性肝炎の時期であれ ばそのほとんどは 1 型インターフェロンでウイルス を排除でき，肝炎は治癒する。

C 型肝炎ウイルス (HCV) により DC 機能が低 下することの最初の報告はマウス脾 DC で検討され た。 HCV コア蛋白を DC 内で発現すると， IL-12 の産生が抑制され DC 機能は低下した ${ }^{38)}$. その後, C 型慢性肝炎患者の未梢血単球から誘導して得た DC の機能は低下することの報告が多い39〜42)，IL12 の産生低下, $\mathrm{NK}$ 細胞と $\mathrm{T}$ 細胞の活性化に重要 な MICA/B というアクセサリー分子の発現の低下 などがあって，DC 機能が低下していた ${ }^{43,44)}$ 。しか し，単球から誘導してえられた DC 機能については 報告者により成績が異なる，筆者らは単球から誘導 した DC を材料にした場合には健常者と比較して差 異がなかったことを報告した ${ }^{45)}$ 。最近， HCV 感染 で単球から誘導した DCには機能低下のないことが 報告されている46,47)。 また，単球および単球由来の DC に HCV の N4 を発現すると IL-10 が産生, IL12 の産生が抑制されることが報告された ${ }^{48)}$ 。単球 および単球から誘導された DC と本来の DC とは機 能面で異なることが考えられる。本来，流血中には 存在しない DCであり, C 型肝炎の病態を理解する 上では限界がある、筆者らは流血中 DC を直接採取 し, その機能と HCV の存在を検討した ${ }^{49)}$. 図 7 に 示したように，流血中 DC 機能は低下していた. 个 ンターフェロンやリバビリン治療で, DC 中の HCVRNA が陰性化するとともに， $\mathrm{T}$ 細胞幼若化補 助能と IL-12 産生能は回復した ${ }^{50)}$. DC には HCV が観察され，末梢血中 HCV とは塩基配列が異なっ ていたが, Lymphocytic choriomeningitis (LCM) ウイルスで観察されたように，DCにある HCV が 特有の塩基配列であることは証明し得なかつた ${ }^{51)}$. DC2 前駆細胞（1 型インターフェロン産生細胞）は

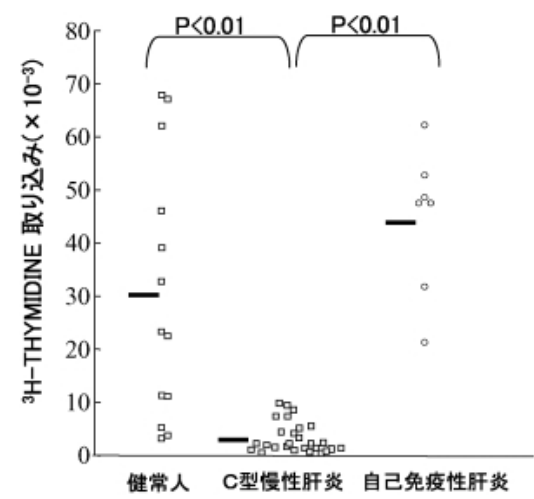

図 $7 \mathrm{C}$ 型慢性肝炎と自己免疫性肝炎に抢ける末梢血樹状細 胞の $\mathrm{T}$ 細胞幼若化補助能

おもな 1 型インターフェロン産生細胞であるが, C 型肝炎ではその機能も低下していた ${ }^{52)}$. Pseudo$\mathrm{HCV}$ を用いた実験系で HCV が E1/2 蛋白を介して myeloid DC 内に進入したが, plasmacytoid DC 内 には進入しなかつたとの報告もある。 myeloid DC に HCV が感染することは明らかとなったが, plasmacytoid DCへ HCV が感染することは否定はでき ないし, plasmacytoid DCの機能が低下している機 構も説明できない53)．HCV 感染でこの細胞がどの ように影響されるかは C 型肝炎の慢性化機構や治 療法の開発をめぐって重要な課題となっている. C 型慢性肝炎にも DC を用いたワクチン治療が試みら れているが悲観的な報告がある.

$\mathrm{C}$ 型慢性肝炎でインターフェロンが無効であった 症例には，肝硬変への進展阻止と発癌抑制を目標に 血清トランスアミナーゼの低下を各種薬剤で行って いる。その最も有効な薬剂はSNMCである.

ConA 肝炎マウスの肝 DC の IL-10 産生能は有意に 低下していた ${ }^{54)}$ 。しかし，in vivoでグリチルリチ ンを投与しておくと，肝 DC の IL-10 産生能は回 復し, ConA 肝炎は抑制されていた。 In vitro で肝 DC にグリチルリチンを投与しても IL-10 産生は回 復した。 以上から DC に対してグリチルリチンは IL-10 産生の回復ないしは IL-12 産生抑制によって Th1 系への免疫応答を抑制し肝炎を沈静化すると考 えられる55)。

\section{VI. 肝細胞癌の免疫療法}

わが国では肝細胞癌により年間 35000 人死亡し, 現在も増加している．悪性新生物による死亡順位で 肝細胞癌は男性で 3 位，女性で 4 位である。肝細胞 癌の原因は HCV が $80 \%, \mathrm{HBV}$ が $15 \%$ である。肝 硬変から発生することが多い. 
肝細胞癌では $\mathrm{T}$ 細胞， $\mathrm{NK}$ 細胞を含めた免疫機能 不全が報告されているが，DC の機能も低下してい る. IL-12 や $\mathrm{TNF}-\alpha$ 産生の低下によって，末梢血 DCの Allostimulatory capacity は低下していた ${ }^{56,57)}$.

1 型インターフェロン産生樹状細胞数も実数で低下 していた。また，肝細胞癌組織内には活性化 （CD83 陽性）DC は観察されなかった ${ }^{58)}$.

肝細胞癌に対しては，DC を用いた免疫療法が動 物とヒトで試みられている. 肝癌細胞株と細胞融合 した DC を担癌マウス投与すると腫瘍の発育は有意 に抑制された ${ }^{59)}$ 。 ヒトにおいては外科手術で採取し た肝癌組織のライゼートを DC にパルスして術後の 肝細胞癌患者に投与する治験が試みられている。し かし，症例報告程度であり，まとまった報告はな $\left(^{60)}\right.$. 病期による肝癌関連抗原の変化や免疫応答す る DC の採取などに問題が残されていると思われ $3^{61)}$. 肝細胞癌の癌関連抗原が不明であるととも に，血液の悪性腫瘍と異なり癌細胞を容易に採取で きないことが大きな监路となっている．筆者らは転 移性肝癌モデルを用いて実験を行った後に，アル コール注入療法を行った肝細胞癌組織局所に DC を 投与する治療法を行っている ${ }^{62)}$. その 1 例を図 8 に 示した. 安全性は確認され, 現在治療効果を観察中 である.

\section{VII. 自己免疫性肝疾患の治療と樹状細胞}

自己免疫性肝疾患には原発性胆汁性肝硬変 $(\mathrm{PBC})$, 自己免疫性肝炎 (AIH) と原発性硬化性
胆管炎（PSC）がある.わが国は PBC 1〜2 万人， AIH5 千から 1 万人の患者が存在すると言われてい る. AIH は副腎皮質ホルモンが著効するが, 劇症 肝炎となると治療抵抗性である.PBC と PSC には 原因療法がなく, 治療に難渋している. 肝移植が最 終的な治療となっている.

原発性胆汁性肝硬変 (PBC) の末梢血 DC 機能 (Allostimulatory capacity) は低下していた ${ }^{45)}$ 。そ の主な原因は DC の一酸化窒素（NO）産生六進で あった。 Bezafibrate を投与すると NO 産生は抑制 され, Allostimulatory capacity は回復していた. PBC の肝組織内には活性化 DC（CD83 陽性）の浸 潤が主に門脈域内に観察された ${ }^{63,64)}$. 血中抗ミトコ ンドリア抗体陰性の PBC 患者においても, AMA の対応抗原である $\mathrm{PDC}$ を $\mathrm{DC}$ にパルスすると $\mathrm{T}$ 細 胞の幼若化反応が全例で観察された ${ }^{65)}$ 。血清中 AMA 陰性でも PDC に感作された $\mathrm{T}$ 細胞は存在す ることが証明されたことは Autoimmune cholangiopathy が PBC に含まれることを示唆する成績と 考えられる. AIH や PSCでの DC の解析はほとん ぞ行われていない．高分化肝細胞癌と DC を瘾合し た細胞をマウスに投与するとAIH と類似した病変 が生じることが報告されている66). AIH では Allostimulatory capacity は低下していなかった ${ }^{33)}$. $\mathrm{PBC}$ と異なる病態である. $\mathrm{AIH}$ と PBC の末梢血 $\mathrm{DC} 1$ と $\mathrm{DC} 2$ を表面マーカーで同定すると, DC2 の HLADR と CD123 のレベルが低下していた ${ }^{67)}$.さ らに, 動物実験ではあるが抗原をパルスした免疫寛

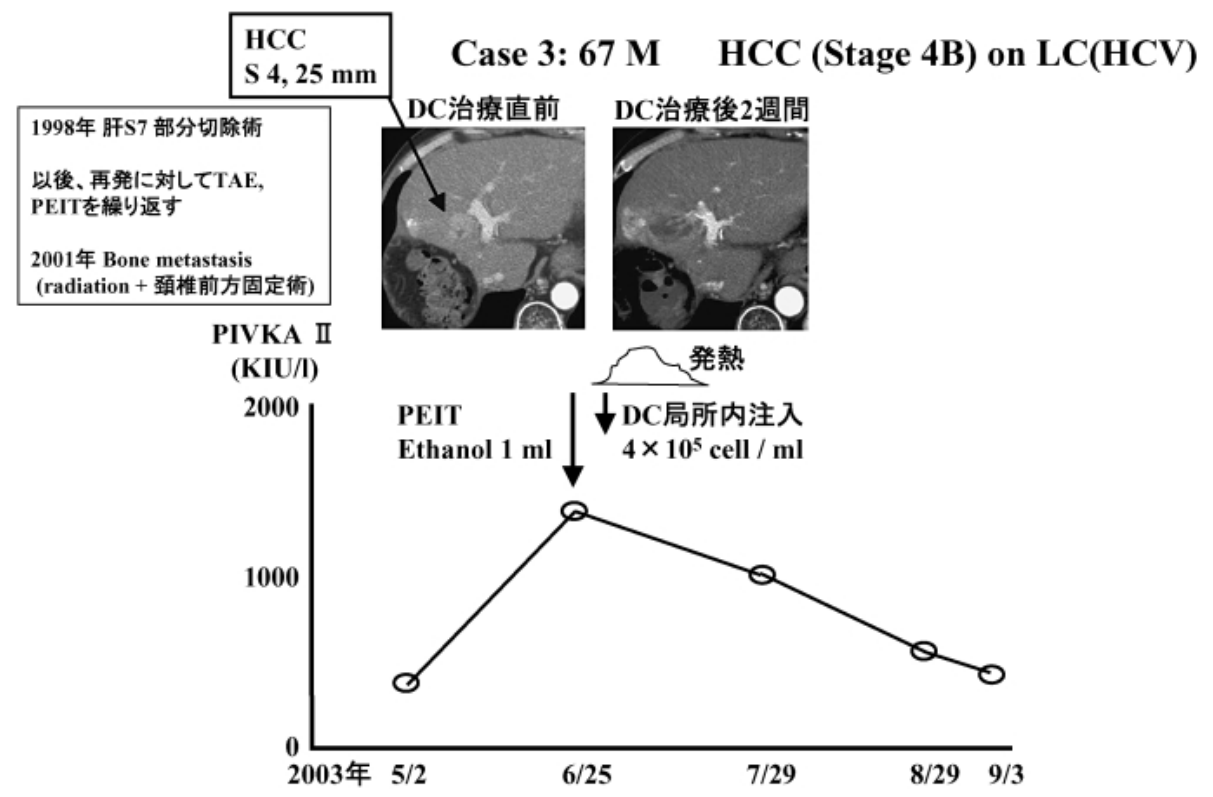

図 8 PEI で治療した腫瘍内に樹状細胞を投与した肝細胞癌の 1 例 
容性 DC を用いて自己免疫性疾患に対する治療法が 開発されている68,69). 今後, 自己免疫性肝疾患であ る $\mathrm{PBC} や \mathrm{AIH}$ の治療への応用が期待される。筆 者らはPBC モデルマウスを用いて, 免疫寛容性 DC による治療法を開発中である.

\section{VIII. ま と め}

免疫学は疾患の診断と病態の解明には大きな役割 を果たしてきた. しかし，どの領域でもいえること であるが, 免疫学が具体的に治療に貢献しているこ とは意外と少ない，肝疾患においても，その病態に 免疫異常が関っていることが明白であるが, 免疫学 が肝疾患の治療法の開発に応用され成功したことは 少ない. しかし, DC の研究成果が蓄積されるとと もに，免疫刺激作用のある DC によるウイルス肝炎 や肝細胞癌の治療, 免疫寛容性 DC による自己免疫 性肝疾患の治療法の開発が進んでいる. なかでも, 肝細胞癌と B 型慢性肝炎に対するワクチン療法は 臨床応用が開始された。 今後, 臨床効果が期待され る. 治療医学として, DC 研究は今後に大きな夢の ある研究領域である.

\section{文献}

1) Banchereau J, Briere F, Caux C, et al. : Immunobiology of dendritic cells. Annu Rev Immunol 18 : 767-811, 2000.

2) Lotze MT and Thomson AW : Dendritic Cells. Academic Press, San Diego, 2001.

3）恩地森一：樹状細胞と臨床. マイライフ社, 東京, 1999.

4) Jego G, Palucka AK, Blanck JP, et al. : Plasmacytoid dendritic cells induce plasma cell differentiation through type I interferon and interleukin 6. Immunity 19 : 225-234, 2003.

5) Onji $\mathrm{M}$ : Dendritic Cells in Clinics, SpringerVerlag, Tokyo, 2003.

6) O'Farrelly C, Crispe IN : Prometheus through the looking glass : reflections on the hepatic immune system. Immunol Today $20: 394-398$, 1999.

7) Mehal WZ, Azzaroli F, Crispe IN : Immunology of the healthy liver : old questions and new insights. Gastroenterology $120: 250-260,2001$.

8) Kita H, Mackay IR, Van De Water J et al. : The lymphoid liver : considerations on pathways to autoimmune injury. Gastroenterology 120 : 1485-1501, 2001.

9) Jaeschke $\mathrm{H}$ : Cellular adhesion molecules : regulation and functional significance in the pathogenesis of liver diseases. Am J Physiol 273 : G602-611, 1997.

10) Tsuneyama $K$, Harada $K$, Yasoshima $M$, et al. : Monocyte chemotactic protein-1,-2 and -3 are distinctively expressed in portal tracts and granulomata in primary biliary cirrhosis : implications for pathogenesis. J Pathol 193 : 102109, 2001.

11) Takeda K, Hayakawa $Y$, Van Kaer L, et al. : Critical contribution of liver natural killer $\mathrm{T}$ cells to a murine model of hepatitis. Proc Natl Acad Sci USA 97 : 5498-5503, 2000.

12) Tseng CT, Miskovsky E, Houghton $M$ et al. : Characterization of liver T-cell receptor $\gamma \delta+\mathrm{T}$ cells obtained from individuals chronically infected with hepatitis $\mathrm{C}$ virus ( $\mathrm{HCV}$ ) : Evidence for these $\mathrm{T}$ cells playing a role in the liver pathology associated with $\mathrm{HCV}$ infections. Hepatology 33 : 1312-1320, 2001.

13) Matsuno $K$, Ezaki $T$ : Dendritic cell dynamics in the liver and hepatic lymph. Int Rev Cytol 197 : 83-136, 2000.

14) Woo J, Lu L, Rao AS, et al. : Isolation, phenotype, and allostimulatory activity of mouse liver dendiritic cells. Transplantation 58 : 484-491, 1994.

15) Knolle PA, Schmitt E, Jin S, et al. : Induction of cytokine production in naive $\mathrm{CD} 4+\mathrm{T}$ cells by antigen-presenting murine liver sinusoidal endothelial cells but failure to induce differentiation toward Th1 cells. Gastroenterology 116 : 1428-1440, 1999.

16) Abe M, Akbar SMF, Horiike N, et al. : Induction of cytokine production and proliferation of memory lymphocytes by murine liver dendritic cell progenitors : role of these progenitors as immunogenic resident antigen-presenting cells in the liver. J Hepatol $34: 61-67,2001$.

17) Crispe IN : Hepatic T cells and liver tolerance. Nat Rev Immunol, 3 : 51-62, 2003.

18) Akbar SMF, Onji M, Inaba K, Yamamura $K-I$, Ohta $\mathrm{Y}$ : Low responsiveness of hepatitis B virus-transgenic mice in antibody response to $\mathrm{T}$-cell dependent antigen : defect in antigenpresenting activity of dendritic cells. Immunology 78 : 468-475, 1993.

19) Akbar SMF, Inaba $K$, Onji $M$ : Upregulation of MHC classs II antigen on dendritic cells from hepatitis B virus transgenic mice by interferongamma : abrogation of immune response defect 
to a $\mathrm{T}$-cell-dependent antigen. Immunology 87 : 519-527, 1996.

20) Kurose K, Akbar SNF, Yamamoto K, Onji M : Production of antibody to hepatitis B surface antigen (anti-HBs) by murine hepatitis B virus carriers : neonatal tolerance versus antigen presentation by dendritic cells. Immunology 92 : 494-500, 1997.

21) Kumon I, Onji M, Nadano S, Kanaoka M, Ohta Y : Detection of hepatitis B surface antigen in lymphoid follicle in patients with chronic hepatitis type B. Gastroenterol Jpn 24:738, 1989.

22) Kumon I : In situ characterization of mononuclear cell phenotype in intrahepatic lymphoid follicles in patients with chronic viral hepatitis. Gastroenterol Jpn 27 : 638-645, 1992.

23) Abe M, Akbar SMF, Horiike N, Onji M : Induction of cytokine production and proliferation of memory lymphocytes progenitors as immunogenic resident antigen-presenting cells in the liver : J Hepatol 34 : 67-71, 2001.

24) Tanimoto K, Akbar SMF, Michitaka K, Horiike N, Onji M : Antigen-presenting cells at the liver tissue in patients with chronic viral liver diseases : CD83-positive mature dendritic cells at the vicinity of focal and confluent necrosis : Hepatol Res 21 : 117-125, 2001.

25) Arima S, Akbar SMF, Michitaka K, Horiike N, Nuriya H, Kohara M, Onji M : Impaired function of antigen-presenting dendritic cells in patients with chronic hepatitis $\mathrm{B}$ : localization of HBV DNA and HBV RNA in blood DC by in situ hybridization. Int J Mol Med 11 : 169174, 2003.

26) Wang FS, Xing LH, Liu MX, et al. : Dysfunction of peripheral blood dendritic cells from patients with chronic hepatitis B virus infection. World J Gastroenterol 7 : 537-541, 2001.

27) Lohr HF, Pingel S, Bocher WO, et al. : Reduced virus specific $\mathrm{T}$ helper cell induction by autologous dendritic cells in patients with chronic hepatitis B-restoration by exogenous interleukin-12. Clin Exp Immunol 130 : 107114, 2002.

28) Horiike N, Akbar SMF, Ninomiya T, Abe M, Michitaka K, Onji M : Activation and maturation of antigen-presenting dendritic cells during vaccine therapy in patients with chronic hepatitis due to hepatitis B virus: Hepatol Res 23 : 38-47, 2002.
29) Akbar SMF, Horiike N, Onji M, et al. : Dendritic cells and chronic hepatitis virus carriers. Intervirology 44 : 199-208, 2001.

30) Akbar SMF, Horiike N, Onji M : Prognostic importance of antigen-presenting dendritic cells during vaccine therapy in a murine hepatitis B virus carrier. Immunology 96 : 98-108, 1999.

31) Akbar SMF, Kajino K, Tanimoto K, Kurose K, Masumoto T, Michitaka K, Horiike N, Onji $\mathrm{M}$ : Placebo-controlled trial of vaccination with hepatitis B virus surface antigen in hepatitis B virus transgenic mice. J Hepatol 26 : 131-137, 1997.

32) Akbar SMF, Abe M, Masumoto T, Horiike N, Onji M : Mechanism of action of vaccine therapy in murine hepatitis B virus carriers : vaccine-induced activation of antigen presenting dendritic cells. J Hepatol 30 : 755-764, 1999.

33) Oka Y, Akbar SMF, Horiike N, Joko K, Onji $\mathrm{M}$ : Mechanism and therapeutic potential of DNA-based immunization against the envelope proteins of hepatitis $\mathrm{B}$ virus in normal and transgenic mice : Immunology 103:90-97, 2001.

34) Akbar SMF, Furukawa S, Horiike N, Michitaka K, Onji M. (submitted).

35) Furukawa S, Akbar SMF, Hasebe A, Horiike $\mathrm{N}$, Onji $\mathrm{M}$. : Induction and maintenance of anti-HBs in immunosuppressed murine hepatitis B virus carrier by a novel vaccination approach: implication during liver transplantation in hepatitis B virus infected subjects $\mathbf{J}$. Gastroenteral (in press).

36) Furukawa S, Akbar SMF, Hasebe A, Horiike N, Onji M. (submitted).

37) Akbar SMF, Furukawa S, Onji M, Murata $Y$, Niiya T, Kanno S, Murakami H, Horiike N. : Safety and efficacy of hepatitis B surface antigen-pulsed dendritic cells in human volunteers Hepatol Res (in press).

38) Hiasa Y, Horiike N, Akbar SMF, Saito I, Miyamura T, Matsuura Y, Onji M : Low stimulatory capacity of lymphoid dendritic cells expressing hepatitis $\mathrm{C}$ virus genes. Biochem Biophys Res Commun 249 : 90-95, 1998.

39) Kanto T, Hayashi N, Takehara T, et al. : Impaired allostimulatory capacity of peripheral blood dendritic cells recovered from hepatitis $\mathrm{C}$ virus-infected individuals. J Immunol 162 : 5584-5591, 1999.

40) Bain C, Fatmi A, Zoulim F, et al : Impaired al- 
lostimulatory function of dendritic cells in chronic hepatitis C infection. Gastroenterology 120 : 512-524, 2001.

41) Auffermann-Gretzinger S, Keeffe EB, Levy S : Impaired dendritic cell maturation in patients with chronic, but not resolved, hepatitis $\mathrm{C}$ infection. Blood 97 : 3171-3176, 2001.

42) Sarobe P, Lasarte JJ, Casares N, et al. : Abnormal priming of $\mathrm{CD} 4(+) \mathrm{T}$ cells by dendritic cells expressing hepatitis $\mathrm{C}$ virus core and $\mathrm{E} 1$ proteins. J Virol 76 : 5062-5070, 2002.

43) Jinushi M, Takehara T, Tatsumi $T$, et al. : Autocrine/paracrine $\mathrm{IL}-15$ that is required for type I IFN-mediated dendritic cell expression of MHC class I-related chain A and B is impaired in hepatitis $\mathrm{C}$ virus infection. $J$ Immunol 15 : 5423-5429, 2003.

44) Jinushi M, Takehara T, Kanto T, et al. : Critical role of MHC class I-related chain A and B expression on IFN-alpha-stimualted dendritic cells in NK cell activation : impairement in chronic hepatitis $\mathrm{C}$ virus infection. J Immunol 170 : 1249-1256, 2003.

45) Yamamoto K, Akbar SMF, Masumoto T, Onji $\mathrm{M}$ : Increased nitric oxide (NO) production by antigen-presenting dendritic cells is responsible for low allogeneic mixed leucocyte reaction (MLR) in primary biliary cirrhosis (PBC) . Clin Exp Immunol 114 : 94-101, 1998.

46) Longman RS, Talal AH, Jacobson IM, et al. : Presence of funotional dendritic cells in patients chronically infected with hepatitis $\mathrm{C}$ virus. Blood, 103 : 1026-1029, 2004.

47) Rollier C, Drexhage JR, Verstrepen BE, et al. : Chronic hepatitis $\mathrm{C}$ virus infection established and maintained in chimpanzees independent of dendritic cell impairment. Hepatology 38 : 851858, 2003.

48) Brady MT, MacDonald AJ, Rowan AG, et al. : Hepatitis $C$ virus non-structural protein 4 suppresses Th1 responses by stimulating IL-10 production from monocytes. Eur J Immunol 33 : 3448-3457, 2003.

49) Tsubouchi E, Akbar SMF, Horiike N, et al. : Infection and dysfunction of circulatingblood dendritic cells and their subsets in chronic hepatitis C virus infection.J Gastroenterol (in press).

50) Tsubouchi E, Akbar SMF, Murakami H, Horiike N, Onji M. (submitted).

51) Sevilla N, Kunz S, Holz A, et al. : Immunosup- pression and resultant viral persistence by specific viral targeting of dendritic cells. J Exp Med 192 : 1249-1260, 2000.

52) Murakami H, Akbar SMF, Matsui H, Horiike N, Onji M. (submitted).

53) Matsuura Y, Tani H, Suzuki K, et al. : Characterization of pseudotype VSV possessing HCV envelope proteins. Virology $286: 263-275$, 2001.

54) Abe M, Akbar SMF, Horiike N, Onji M : Inability of liver dendritic cells from mouse with experimental hepatitis to process and present specific antigens : Hepatol Res 26 : 61-67, 2003.

55) Abe M, Akbar SMF, Horiike N, Onji M : Glycyrrhizin enhances interleukin-10 production by liver dendritic cells in mice with hepatitis. J Gastroenterol 38 : 962-967, 2003.

56) Ninomiya $T$, Akbar SMF, Masumoto $T$, Horiike N, Onji M : Dendritic cells with immature phenotype and defective function in the peripheral blood from patients with hepatocellular carcinoma. J Hepatol 31 : 323-331, 1999.

57) Kakumu $S$, Ito $S$, Ishikawa $T$, et al. : Decreased function of peripheral blood dendritic cells in patients with hepatocellular carcinoma with hepatitis B and C virus infection. J Gastroenterol Hepatol 15 : 431-436, 2000.

58) Chen S, Akbar SMF, Tanimoto K, Ninomiya T, Iuchi H, Michitaka K, Horiike N, Onji M : Absence of CD83-positive mature and Activated dendritic cells at cancer nodules from patients with hepatocelluar carcinoma: relevance to hepatocarcinogenesis. Cancer Lett $148:$ 49-57, 2000.

59) Homma S, Toda G, Gong J, et al. : Preventive antitumor activity against hepatocellular carcinoma (HCC) induced by immunization with fusions of dendritic cells and HCC cells in mice. J Gastroenterol 36 : 764-771, 2001.

60) Ladhams A, Schmidt C, Sing G, et al. : Treament of non-resectable hepatocellular carcinoma with autologous tumor-pulsed dendritic cells. J Gastroetnerol Hepatol 17 : 889-896, 2002.

61) Onji M, Akbar SMF, Horiike N : Dendritic cell-based immunotherapy for hepatocellular carcinoma : J Gastroenterol 36 : 794-797, 2001.

62) Kumagi T, Akbar SMF, Horiike N, et al. : Increased survival and decreased tumor size due to intratumoral injection of ethanol followed by administration of immature dendritic cells. Int 
J Oncol 23 : 949-955, 2003.

63) Shinomiya $M$, Masumoto $T$, Nadano $S$, Akbar SMF, Onji M : Lymphoid dendritic cells in the liver of patients with primary biliary cirrhosis and its mouse model. Hepatol Res $1: 84-94$, 1998.

64) Tanimoto K, Akbar SMF, Michitaka K, Onji $M$ : Immunohistochemical localization of antigen presenting cells in liver from patients with primary biliary cirrhosis : highly restricted distribution of CD83-positive activated dendritic cells. Pathol Res Pract 195 : 157-162, 1999.

65) Akbar SMF, Yamamoto $\mathrm{K}$, Miyakawa $\mathrm{H}$, Ninomiya T, Abe M, Hiasa Y, Masumoto T, Horiike N, Onji M : Peripheral blood T-cell responses to pyruvate dehydrogenase complex in primary biliary cirrhosis : role of antigenpresenting dendritic cells : Eur J Clin Invest 31 :
639-646, 2001.

66) 本間 定, 玉城成雄, 榎本宏樹, ほか：樹状 細胞を用いた自己免疫性肝炎モデルにおける 抗肝細胞膜抗体の検出. 肝臓, $41: \mathrm{A} 193$, 2000 (抄録).

67) Hiasa Y, Akbar SMF, Abe M, Michitaka K, Horiike N, Onji M : Dendritic cell subtypes in autoimmune liver diseases; decreased expression of HLA DR and CD 123 on type 2 dendritic cells : Hepatol Res 22 : 241-249, 2002.

68) Huang YM, Yang JS, Xu LY, et al. : Autoantigen-pulsed dendritic cells induce tolerance to experimental allergic encephalomyelitis (EAE) in Lewis rats. Clin Exp Immunol 122 : 437-444, 2000.

69) Mahnke K, Knop J, Enk AH : Induction of tolerogenic DCs: 'you are what you eat'. Trends Immunol 24 : 646-651, 2003. 